\title{
Worm in vermiform appendix: a surgeon's perspective
}

\author{
Ravikiran Naalla, ${ }^{1}$ Sankalp, ${ }^{1}$ Prashanth Shetty, ${ }^{1}$ Vikas Sud ${ }^{2}$
}

${ }^{1}$ Department of General Surgery, Kasturba Medical College, Manipal, Karnataka, India

${ }^{2}$ Department of Orthopaedics, Kasturba Medical College, Manipal, Karnataka, India

\section{Correspondence to} Dr Ravikiran Naalla, ravi_2488@yahoo.co.in

Accepted 13 June 2014

\section{CrossMark}

To cite: Naalla $R, S$, ShettyP, et al. BMJ Case Rep Published online: [please include Day Month Year] doi:10.1136/bcr-2014205411

\section{DESCRIPTION}

A 23-year-old man presented to us with reports of right-sided lower abdominal pain for 1 day associated with anorexia and nausea. Abdominal ultrasound scan showed inflammed appendix. His routine blood investigations revealed mild neutrophilic leucocytosis and eosinophilia. He was taken up for emergency laparoscopic appendicectomy. Intraoperatively, after dividing the appendix between the endoloop ligatures three pinworms (Entrobious vermicularis) fell into the abdomen. One of them reached the abdominal wall (figure 1), and its movement can be seen (video 1). All three of them were extracted using blunt grasper. Appendix specimen was cut open and we found one more pinworm in it (figure 2). He was prescribed albendazole $400 \mathrm{mg} /$ week for two doses. The patient is asymptomatic after 2 months of follow-up.

Entrobius vermicularis is the most common helminthic infection, it is most frequently observed in children aged 5-10 years. Humans are the only natural host. The lifecycle begins when the gravid female deposits eggs in the perianal area. Following ingestion, eggs are hatched and larvae are produced in the small intestine. However, caecum and appendix are usual sites of infestation. Usually pinworm infections are symptomatic with the most common symptom being perianal itching. Occasionally symptoms like nausea, abdominal pain or diarrhoea may be present.

Incidence of pinworms in patients with symptoms of appendicitis is $0.2-41.8 \%{ }^{1}$ but appendiceal

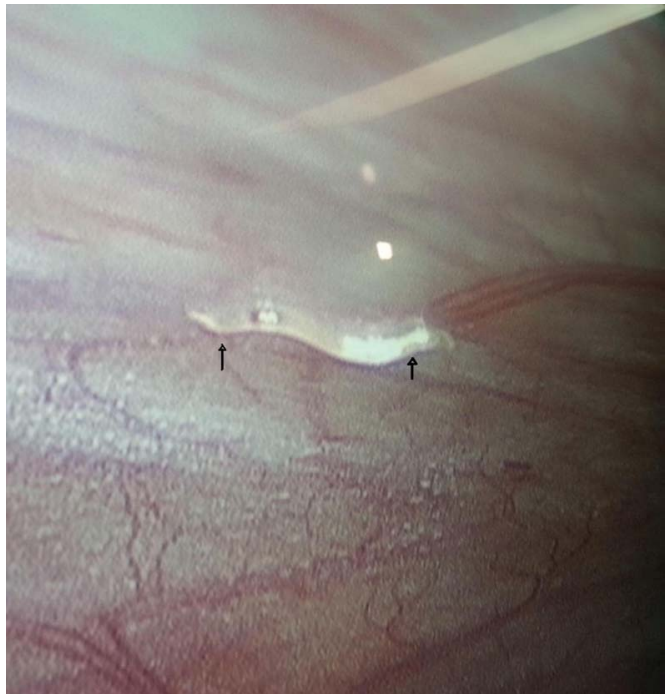

Figure 1 Digital image showing pinworm over the abdominal wall (indicated by black arrows).

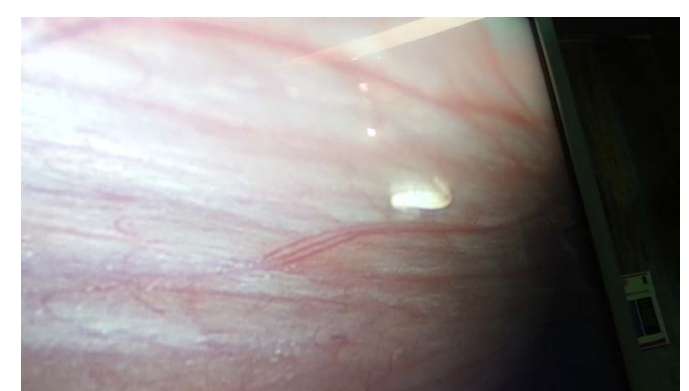

Video 1 Video clip showing pin worm moving over the parietal peritoneum.

infestation itself is the cause of appendicitis which is still under debate. ${ }^{2}$ Pinworms may obstruct the lumen of appendix, or they may elicit hypersensitivity reaction in the tissues causing clinical picture

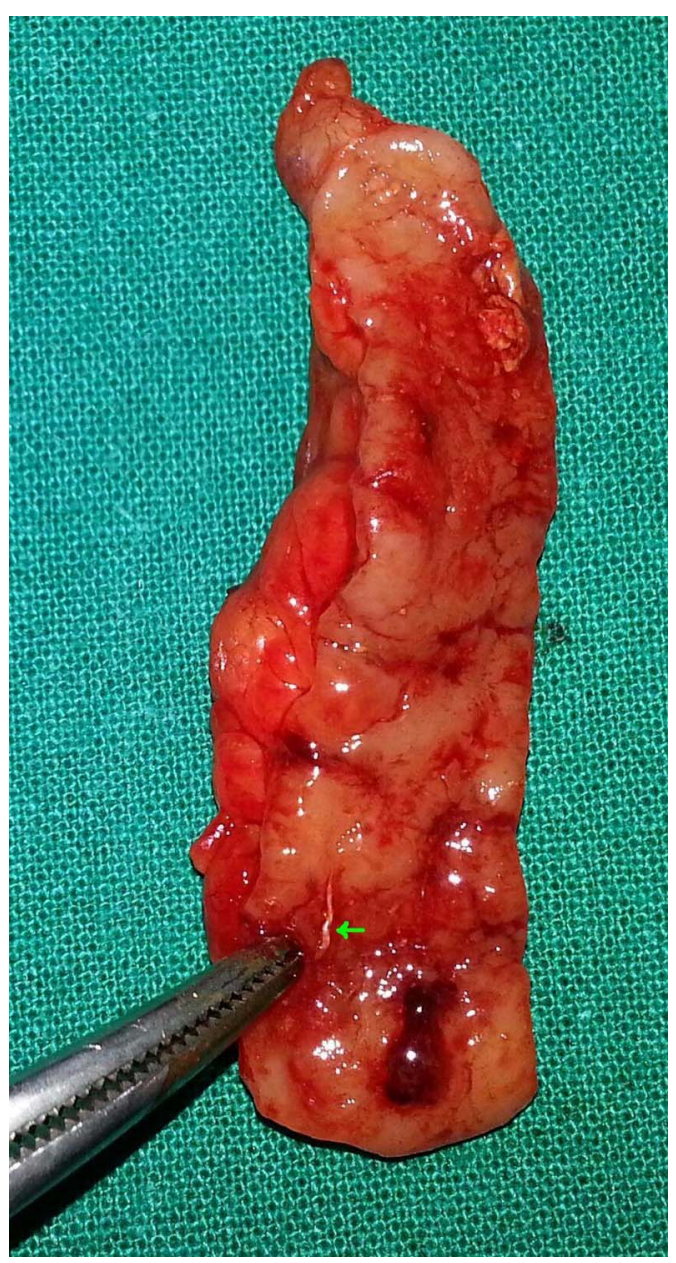

Figure 2 Digital image showing cut open appendix specimen with pinworm in situ (indicated by artery forceps and green arrow). 
of acute appendicitis. ${ }^{3}$ However, only $13-37 \%$ of appendices infested with pinworms are inflamed. ${ }^{1}$ Treatment of enterobiasis consists of antihelmenthic drugs (albendazole $400 \mathrm{mg}$ once and to repeat after 1 week). Surgeons must be aware of the

\section{Learning points}

- Incidence of pinworms in patients with symptoms of appendicitis is $0.2-41.8 \%$. Appendiceal infestation itself is the cause of appendicitis which is still under debate.

- Surgeons must be aware of the possibility of pinworm infestation in the appendix and one should avoid the contamination of the abdomen with pinworms while performing appendicectomy.

- If there is spillage of worms in the abdomen they must be dealt by diathermy or endoscopic suctioning. possibility of pinworm infestation in the appendix and one should avoid the contamination of the abdomen with pinworms while performing appendicectomy. Contamination of the abdomen may be prevented by cutting the appendix bit by bit while maintaining traction over the appendix. If there is spillage of worms into the abdomen they must be dealt by diathermy or endoscopic suctioning.

Contributors RKN contributed to manuscript preparation and publishing. Sankalp was the operating surgeon. VS and PS proof read the article.

Competing interests None.

Patient consent Obtained.

Provenance and peer review Not commissioned; externally peer reviewed.

\section{REFERENCES}

1 Dahlstrom JE, Macarthur EB. Enterobius vermicularis: a possible cause of symptoms resembling appendicitis. Aust NZ J Surg 1994;64:692-4.

2 Stĕrba J, Vlcek M. Appendiceal enterobiasis - its incidence and relationships to appendicitis. Folia Parasitol (Praha) 1984;31:311-18.

3 Henley M, Sears JR. Pinworms: a persistent pediatric problem. MCN Am J Matern Child Nurs 1985:10:111-13.

Copyright 2014 BMJ Publishing Group. All rights reserved. For permission to reuse any of this content visit http://group.bmj.com/group/rights-licensing/permissions.

BMJ Case Report Fellows may re-use this article for personal use and teaching without any further permission.

Become a Fellow of BMJ Case Reports today and you can:

- Submit as many cases as you like

- Enjoy fast sympathetic peer review and rapid publication of accepted articles

- Access all the published articles

- Re-use any of the published material for personal use and teaching without further permission

For information on Institutional Fellowships contact consortiasales@bmjgroup.com

Visit casereports.bmj.com for more articles like this and to become a Fellow 